\title{
Humoral Immune Response in a Mouse Model Induced With Dengue Virus-like Particles Serotypes 1 and 4 Produced in Silkworm Larvae
}

Doddy Irawan

Shizuoka Daigaku

Sabar Pambudi

National Research and Innovation Agency

Enoch Y. Park ( $\nabla$ park.enoch@shizuoka.ac.jp )

Shizuoka University https://orcid.org/0000-0002-7840-1424

Original article

Keywords: Dengue virus, Capsid, Premembrane, Envelope, Dengue virus-like particle, Silkworm

Posted Date: November 22nd, 2021

DOI: https://doi.org/10.21203/rs.3.rs-1085378/v1

License: (c) (i) This work is licensed under a Creative Commons Attribution 4.0 International License.

Read Full License 


\section{Abstract}

Dengue is an arboviral disease, which threatens almost half the global population, and has emerged as the most significant of current global public health challenges. In this study, we prepared dengue viruslike particles (DENV-LPs) consisting of Capsid-Premembrane-Envelope (CprM/E) and PremembraneEnvelope (prM/E) polypeptides from serotype 1 and 4, which were expressed in the silkworms using Bombyx mori nucleopolyhedrovirus (BmNPV) bacmid. 1CprME, 1prME, 4CprME, and 4prME expressed proteins in hemolymph and molecular weight of the purified proteins were $55 \mathrm{kDa}$, respectively. The purified polypeptides formed spherical Dengue virus-like particles (DENV-LPs) with approximately 30-55 $\mathrm{nm}$ in diameter. The immunoelectron microscopy (IEM) images revealed antigens to the surface of a lipid bilayer of DENV-LPs. The heparin-binding assay shows a positive relationship between absorbance and the quantity of E protein domain III (EDIII), which was supported by the isothermal titration calorimetry assay, showing a moderate binding affinity between heparin and DENV-LP. The high correlation between patient sera and DENV-LP reactivities revealed that these DENV-LPs shared similar epitopes with the natural dengue virus. IgG elicitation studies in mice have demonstrated that DENV-LP/CPrMEs elicits a stronger immune response than DENV-LP/prMEs, which lends credence to this claim.

\section{Key Points}

- Dengue virus-like particles for serotype 1 and serotype 4 (DENV-LPS/1 and DENV-LPS/4) were produced in silkworm.

- Heparin-binding assay by ELISA and ITC showed that DENV-LPS/1 and DENV-LPS/4 contain Envelope Domain III.

- DENV-LPS/1 and DENV-LPS/4 showed affinity to sera from human dengue patients and immunizedmice.

\section{Introduction}

Dengue fever is a significant public health issue that has been reported in the Americas, Africa, Southeast Asia, Europe, the Western Pacific, and the Eastern Mediterranean. This arboviral disease is endemic in more than 100 countries, this, and approximately 96 million infected individuals have symptoms of varying severities. There has been a growing public health concern about dengue fever in the last few decades. The World Health Organization (WHO) named it one of the top ten global health threats in 2019, highlighting the critical need for a safe and effective vaccine. Despite numerous attempts, identifying the best candidate for a dengue vaccine continues to be a difficult task due to some critical factors that must be considered (Bhatt et al. 2021; Redoni et al. 2020).

Dengue virus (DENV) is the etiological agent, and it has four antigenically distinct serotypes. They belong to the Flavivirus genus and the Flaviviridae family and antigenically similar yet genetically diverse. Adaptive immunity induced by one DENV serotype does not provide long-term protection against infection with the other three heterotypic DENVs. There is $70 \%$ sequence homology between DENV 
serotype 1-4 (DENV-1 - DENV-4), which means that numerous immunogenic epitopes are conserved at some level. DENV is an enveloped virus with a single positive-strand RNA genome that encodes three structural proteins, capsid (C), premembrane (prM), and envelope (E), as well as seven nonstructural proteins (NS1, NS2A, NS2B, NS3, NS4A, NS4B, and NS5) (Redoni et al. 2020; Yousaf et al. 2018).

Based on a 70-year study that examined the spread of DENV worldwide, the most reported strains were DENV-1, DENV-2, and DENV-3, and the least frequently recorded was DENV-4. Although DENV-4 was the first serotype of dengue to diverge in phylogenetic investigations of the Flavivirus genus, it spread slowly worldwide. DENV-1 and DENV-4 cause dengue fever with different degrees of severity. When DENV-1 infection was compared to DENV-4 infections, the duration of fever, which essentially correlates with the severity of the illness, was much longer for DENV-1. DENV-1 infection was also associated with more severe clinical manifestations than DENV-4 infection. Primary DENV-4 infection is a relatively mild sickness, but primary DENV-1 infection has more severe symptoms (Nishiura and Halstead 2007; Sang et al. 2019; Villabona-Arenas and Zanotto 2013).

Virus-like particles (VLPs) are viruses with a shell but no virus-specific genetic material. VLPs may be able to mimic the organization and conformation of wild viruses because they contain multiprotein determinants. The organization and conformation of native viruses can be used to explore virus infection mechanisms and stimulate the host immune system to produce robust immune responses (Roldao et al. 2010). Furthermore, VLPs do not cause infections because they lack the viral genome. These properties of VLPs make them potential vaccine candidates that may be more efficient and safer than conventionally attenuated or inactivated viruses (Noad and Roy 2003).

Two successful approaches have been applied to produce recombinant VLPs of flaviviruses, including capsid-premembrane-envelope (CprME) protein genes and pre-membrane-envelope (prME) proteins in cis as well as in trans from plasmid vectors. Both types of approaches should result in the formation of particles. Although the $\mathrm{C}$ protein is not required to form particles, the inclusion of $\mathrm{C}$ protein may have a stabilizing effect on VLP assembly. Capsid proteins can be arranged in one, two, or three layers, depending on their size. Some single-layer VLPs can contain more than one structural protein, whereas others cannot. When compared to the structure of single-protein VLPs (which is relatively simple), multiprotein VLPs (which contain several distinct capsid layers) have additional structural components (Krol et al. 2019; Nooraei et al. 2021).

BEVS (baculovirus expression vector system) is a high-level mass production tool for recombinant proteins in silkworm. This enables us to express eukaryotic recombinant proteins with post-translational modifications similar to those found in mammals. The number of recombinant proteins produced by silkworm-BEVS in silkworm larvae is frequently significantly higher than that produced by Sf9-BEVS in cultured cells (Kato et al. 2010; Vipin Kumar Deo 2012). Feeding silkworms is exceptionally inexpensive, with a total cost of approximately USD 20 for twenty larvae. Thus, it costs slightly more than USD 20 to obtain approximately $1 \mathrm{mg}$ of active Protein kinase B alpha (PKBa) (Maesaki et al. 2014). This approach is comparable in cost to an expression system based on Escherichia coli. Furthermore, because 
silkworms have low-cost productivity equal to the $E$. coli expression system, protein production can be quickly and inexpensively scaled up. This expression system is favorable for vaccine development (Fujita et al. 2020).

Previously, we have successfully expressed DENV-LPs serotype 2 (DENV-LP/2CprME, /2E), and DENV-LPs serotype 3 (DENV-LP/3prME, /3CprME) by removing capsid-anchor in the $\mathrm{C}$ region (Utomo et al. 2019; Utomo et al. 2020). In this study, we prepared DENV-LPs consisting full-length of capsid-premembraneenvelope (1 CprME and 4CprME) and premembrane-envelope (1prME and 4prME) polypeptides from serotypes 1 and 4, which were expressed using Bombyx mori nucleopolyhedrovirus (BmNPV) bacmid in silkworms. We observed the formation of VLPs, confirmed envelope domain III (EDIII) of DENV using a heparin binding assay by ELISA and ITC, reactivity toward dengue patient sera, and confirmed the elicitation of antibody production in a mouse model.

\section{Materials And Methods}

\section{Construction of recombinant BmNPVs}

The C-prM-E and prM-E polypeptide coding sequences (GenBank: DENV-1 KM204119, DENV-4 KR011349, Genewiz, New Jersey, USA) were used. A linker sequence (GGGGSGGGGS) and HA-tag sequence (YPYDVPDYA) for DENV-1 constructs, a Strep tag-II sequence (WSHPQFEK) for DENV-4 constructs, and a FLAG-tag sequence (DYKDDDDK) for both serotype constructs were fused at the C-terminus using a template (the synthetic gene described above) by polymerized chain reaction (PCR) with a set of primers (1CprME-F, 1CprME-R-EcoRI, 4CprME-F, 4CprME-R-EcoRI, Table 1) and as a template for the coding sequence of DENV-1 C-prM-E, and DENV-4 C-prM-E. To isolate the DENV-1 prM-E and DENV-4 prM-E coding sequences, a primer set (1prME-F, 1prME-R-EcoRI, 4prME-F, 4prME-R-EcoRI, Table 1) was used. The PCR steps began with initial denaturation at $98^{\circ} \mathrm{C}$ for $10 \mathrm{sec}$, followed by 35 cycles of $98^{\circ} \mathrm{C}$ for $10 \mathrm{sec}$, $55^{\circ} \mathrm{C}$ for $5 \mathrm{sec}$, and $72^{\circ} \mathrm{C}$ for $20 \mathrm{sec}$, and finished with $72{ }^{\circ} \mathrm{C}$ for $3 \mathrm{~min}$ for the final extension. The PCR process was carried out using a thermal cycler (TaKaRa, Kyoto, Japan). Each construct was ligated into the pFastbac1 vector (Thermo Fisher Scientific K. K., Tokyo, Japan), and the resulting vector was transformed into E. coli BmDH10bac CP- Chi- BmNPV/1CprME, BmNPV/4CprME, BmNPV/1prME, and BmNPV/4prME bacmids were isolated from white colonies. Each recombinant BmNPV bacmid was combined with chitosan (Sigma-Aldrich, Tokyo, Japan) and administered to fifth instar silkworm larvae (Ehimesansyu, Ehime, Japan). The hemolymph containing recombinant BmNPV was collected from the larvae 6-7 days after injection (dpi) and mixed with 1-phenyl-2-thiourea at $1 \mathrm{mM}$, with aliquots of hemolymph stored at $-80^{\circ} \mathrm{C}$ before use (Boonyakida et al. 2021; Suhaimi et al. 2019; Utomo et al. 2019; Utomo et al. 2020).

Table 1 Used primers 
Name $5-3$

\begin{tabular}{|c|c|}
\hline 1CprME-F & TAA TGG ATC CAT GAA CAA TCA GCG CAA A \\
\hline 1CprME-R-EcoRI & TAA TGA ATT CTC AAG CGT AGT CCG GAA CA \\
\hline 1prME-F & TAA TGG ATC CAT GTT TCA CCT GAC CAC CAG GGG \\
\hline 1prME-R-EcoRI & TAA TGA ATT CTC AAG CGT AGT CCG GAA CA \\
\hline 4CprME-F & TAA T GG ATC CAT GAA CCA GAG GAA AAA AGT \\
\hline 4CprME-R-EcoRI & TAA TGA ATT CTC ATT TTT CGA ACT GGG GG \\
\hline 4prME-F & TAA TGG ATC CAT GTT CCA TCT CTC GAC GCG TGA T \\
\hline 4prME-R-EcoRI & TAA TGA ATT CTC ATT TTT CGA ACT GGG GG \\
\hline pFastBac1-F & TAT TCC GGA TTA TTC ATA CC \\
\hline pFastBac1-R & ACA AAT GTG GTA TGG CTG ATT \\
\hline $\mathrm{pUC/M13-F}$ & CCC AGT CAC GAC GTT GTA AAA CG \\
\hline $\mathrm{pUC/M13-R}$ & AGC GGA TAA CAA TTT CAC ACA GG \\
\hline
\end{tabular}

Underlines indicate restriction enzyme cleavage sites.

\section{Expression and purification}

Fifth instar silkworm larvae (Ehimesansyu) were injected with 100-fold diluted hemolymph in phosphatebuffered saline (PBS) (137 mM NaCl, $2.7 \mathrm{mM} \mathrm{KCl} 8 \mathrm{mM} \mathrm{Na}_{2} \mathrm{HPO}_{4}$, and $2 \mathrm{mM} \mathrm{KH}_{2} \mathrm{PO}_{4}, \mathrm{pH}$ 7.4). They were fed a synthetic diet (Silkmate S2, Nosan Co., Yokohama, Japan). To collect the hemolymph, the larva's leg was cut. The hemolymph was diluted 10-fold with $50 \mathrm{mM}$ Tris- $\mathrm{HCl}(\mathrm{pH} 7.5)$ containing $300 \mathrm{mM} \mathrm{NaCl}$ before being applied to DDDDK-tagged protein purification gel column chromatography (Medical \& Biological Laboratories, Nagoya, Japan). The column was washed with $50 \mathrm{mM}$ Tris- $\mathrm{HCl}(\mathrm{pH} 7.5)$ containing $300 \mathrm{mM} \mathrm{NaCl}$. The proteins were eluted with $0.17 \mathrm{M}$ glycine-HCl buffer $(\mathrm{pH} 2.3)$. The eluents were neutralized immediately with $1 \mathrm{M}$ Tris- $\mathrm{HCl}(\mathrm{pH}$ 8.0). Ultrafiltration was used to concentrate the eluents using an Amicon Ultra-0.5 mL Centrifugal Filter Unit with an Ultracel-30K membrane (Merck Japan, Tokyo, Japan). A BCA protein assay kit was used to determine the protein concentration (Thermo Fisher Scientific K. K.).

\section{Western blot analysis}

To separate the proteins, $10 \%$ or $12 \%$ sodium dodecyl sulfate-polyacrylamide gel electrophoresis (SDSPAGE) was used and subsequently subjected to western blotting by blotting the proteins trapped in acrylamide gel onto an Immobilon-P PVDF (polyvinylidene fluoride) membrane (Merck Japan) using the Mini Trans-Blot Electrophoretic Transfer Cell (Bio-Rad, Hercules, CA, USA). After blotting, the membrane 
was blocked in Tris-buffered saline with $0.1 \%$ Tween 20 detergent (TBST) (pH 7.6) with 5\% skim milk (FUJIFILM Wako Pure Chemical) and then incubated in 10000-fold diluted mouse anti-HA tag antibody (Medical \& Biological Laboratories) for DENV-1 constructs and anti-strap tag II antibody (Medical \& Biological Laboratories) for DENV-4 constructs. Alternatively, 1500-fold diluted specific serotype monoclonal anti-envelope antibodies, anti-E DENV-1 E29 clone (BEl Resources, Virginia, US) for DENV-1 constructs, and anti-E DENV-4 E42 clone (BEI Resources) for DENV-4 constructs were used as the primary antibodies. Anti-E DENV-2 3H5-1 clone (BEI Resources) and anti-E DENV-3 E1 clone (BEI Resources) antibodies were also used to assess cross-reactivity between serotypes for all purified proteins. After three washes with TBST, the membrane was incubated for one hour with 10000 -fold diluted anti-mouse IgG antibody conjugated to horseradish peroxidase (HRP) (FUJIFILM Wako Pure Chemical). The specific bands were discovered using a Fluor-S MAX Multi-Imager (Bio-Rad).

\section{Heparin-binding assay by ELISA}

The heparin-binding assay by ELISA was performed with modifications as previously described (Utomo et al. 2019; Utomo et al. 2020). Six ng/ml diluted biotin-labeled heparin (Sigma-Aldrich Japan) and $1.8 \mathrm{ng}$ of heparin were immobilized into blockless avidin plate (Sumitomo Bakelite, Tokyo, Japan) wells and washed three times with PBS. For a negative control, $2 \mu \mathrm{g}$ of BSA was used. Purified proteins at various concentrations $(0.5,1,5$, and $10 \mathrm{~g} / \mathrm{ml})$ were added to wells at corresponding quantities, incubated at room temperature for one hour, and then washed with PBST. After serial washing, a 1000-fold diluted rabbit anti-DENV E polyclonal antibody (GeneTex) was added, followed by a 1000-fold diluted HRPconjugated anti-rabbit IgG antibody (FUJIFILM Wako Pure Chemical). To stop the reaction, $100 \mu \mathrm{l}$ of substrate $0.1 \mathrm{mg} / \mathrm{ml} 3.3^{\prime}, 5.5^{\prime}$-tetramethylbenzidine (TMB) in $100 \mathrm{mM}$ sodium acetate $\left(\mathrm{CH}_{3} \mathrm{COONa}\right), \mathrm{pH}$ 6.0 , was added to each well with $0.2 \%(\mathrm{v} / \mathrm{v}) 30 \%$ hydrogen peroxide, and $50 \mu \mathrm{l}$ of $1 \mathrm{~N} \mathrm{H}_{2} \mathrm{SO}_{4}$ was added. The absorbance was estimated at $450 \mathrm{~nm}$.

\section{Isothermal Titration Calorimetry assay for heparin binding to DENV-LPs}

The binding affinities of DENV-LP to heparin were determined using isothermal titration calorimetry (ITC) on a MicroCal iTC200 (Malvern Panalytical Ltd, Enigma Business Park, UK). Titrations were performed at a temperature of $25^{\circ} \mathrm{C}$ by injecting $2 \mu \mathrm{l}$ aliquots of $1000 \mu \mathrm{M}$ ligand dissolved in $1 \times$ PBS buffer into a cell containing $10 \mu \mathrm{M}$ DENV-LP. The heat release was recorded, and the titration data were analyzed with MicroCal Origin ITC software (Malvern Panalytical Ltd). Thermodynamic parameters were determined by fitting experimental data with nonlinear least-squares using the one-set sites binding model (Duff et al. 2011; lkegaya et al. 2021).

\section{Human DENV-infected sera interaction with DENV-LPs}

Direct ELISA was carried out with modifications as previously described (Utomo et al. 2019; Utomo et al. 2020). An interaction between antigens, $1 \mathrm{CprME}, 1 \mathrm{prME}, 4 \mathrm{CprME}$, and $4 \mathrm{prME}$, and patient sera was detected using a direct ELISA method. Dengue patient sera [rapid diagnostic test NS1(+)] were used. Sera were obtained from the Centre of Pharmaceutical and Medical Technology, National Research and 
Innovation Agency, Jakarta, Indonesia. Protocols of the collection were reviewed and approved by the Health Research Ethics Committee-University of Indonesia and Cipto Mangunkusumo Hospital (HRECFMUI/CMH) (approval no. KET-1358/UN2.F1/ETIK/PPM.00.02/2020).

Each diluted sample, $100 \mu \mathrm{l}$ of $20 \mathrm{ng} / \mathrm{ml}$ in coating buffer ( $0.05 \mathrm{M}$ carbonate-bicarbonate, $\mathrm{pH}$ 9.6), was applied to a 96-well ELISA plate and incubated overnight at $4{ }^{\circ} \mathrm{C}$. After incubation, the coating solution was discarded, and a $100 \mu \mathrm{l}$ blocking solution (5\% skim milk in PBS) was added to each well, followed by $1 \mathrm{~h}$ at $37^{\circ} \mathrm{C}$ incubation. The plates were then washed serially with PBST buffer before adding $100 \mu \mathrm{l}$ of 1:50 patient sera in PBS. Plates were then incubated at $37^{\circ} \mathrm{C}$ for $1 \mathrm{~h}$ before being washed three times with washing buffer and before the addition of $100 \mu$ of 1:5000 anti-human IgG-HRP conjugated antibody. Plates were then incubated at $37^{\circ} \mathrm{C}$ for $1 \mathrm{~h}$ and washed, and $50 \mu \mathrm{l}$ of TMB substrate was applied and incubated for $10 \mathrm{~min}$ before being stopped with $50 \mu \mathrm{l}$ of $1 \mathrm{M} \mathrm{H}_{2} \mathrm{SO}_{4}$. The absorbance was measured at $450 \mathrm{~nm}$.

\section{Immunoelectron microscopy}

Immunoelectron microscopy (IEM) was carried out as previously described (Utomo et al. 2020) with modifications. The purified antigen sample was added to the $\mathrm{Cu}$-grid transmission electron microscopy (TEM) (Nisshin EM Co., Ltd., Tokyo) and incubated for $30 \mathrm{sec}$ at room temperature, washed with $30 \mu \mathrm{l}$ of PBS, and incubated for $30 \mathrm{sec}$, repeated three times. BSA ( $30 \mu \mathrm{l}$ of $2 \% \mathrm{v} / \mathrm{v})$ was used for blocking after adding a purified antigen sample and washed three times with PBS. The Cu-grid was washed in stages. The first and secondary antibodies were anti-E rabbit polyclonal antibody (FUJIFILM Wako Pure Chemical) diluted 30 times and goat anti-rabbit IgG-conjugated (FUJIFILM Wako Pure Chemical) gold nanoparticles diluted 50 times, respectively. The Cu grid was treated with $1 \%$ phosphotungstic acid and analyzed with a JEM-2100F TEM system (JEOL Ltd., Tokyo, Japan).

\section{Mice immunization}

Mouse immunization was carried out as previously described (Utomo et al. 2020) with modifications. In this study, 50 BALB/c mice aged 4-6 weeks were divided into ten groups: i) negative control (PBS), ii) immunized with alhydrogel as an adjuvant, iii) immunized with 1 CprME, iv) immunized with 1CprME+adjuvant, v) immunized with $1 \mathrm{prME}$, vi) immunized with 1 prME+adjuvant, vii) immunized with 4CprME, viii) immunized with 4CprME+adjuvant, ix) immunized with 4prME, and $\mathrm{x}$ ) immunized with $4 p r M E+a d j u v a n t$. All mice were kept in a temperature-controlled, light-cycled room and were divided into ten groups based on the immunogen. Each mouse was immunized three times intraperitoneally within two weeks with $50 \mathrm{mg}$ of purified $1 \mathrm{CprME}, 1 \mathrm{prME}, 4 \mathrm{CprME}$, and $4 \mathrm{prME}$ proteins with alhydrogel adjuvant. Blood samples were collected via the tail vein on Days 0,16 , and 30 , and sera were isolated and stored at $-80^{\circ} \mathrm{C}$. All animal procedures were conducted in compliance with established guidelines from the Animal Laboratory of Center of Pharmaceutical and Medical Technology, National Research and Innovation Agency, Indonesia. Animal experiment protocols were reviewed and approved by the Health Research 
Ethics Committee-University of Indonesia and Cipto Mangunkusumo Hospital (HREC-FMUI/CMH) (approval no. KET-721/UN2.F1/ETIK/PPM.00.02/2021).

\section{Results}

\section{Expression of 1CprME, 1prME, 4CprME and 4prME polypeptides in silkworm}

DENV structural proteins are composed of a $\mathrm{C}$ and two membrane proteins, prM and $\mathrm{E}$, translated at the beginning of the polyprotein in the order C-prM-E. BmNPV/1CprME (Fig. 1a), BmNPV/1prME (Fig. 1b), BmNPV/4CprME (Fig. 1C), and BmNPV/4prME (Fig. 1d) bacmids were injected into silkworm larvae, and the silkworm hemolymph was collected at $5 \mathrm{dpi}$. The expression of 1CprME, 1prME, 4CprME, and 4prME in hemolymph samples was confirmed, with molecular weights of $55 \mathrm{kDa}$ at the E protein (Fig. S1 of Supplementary Information), which corresponded to the estimated weight.

\section{Purification of 1CprME, 1prME, 4CprME and 4prME polypeptides}

The 1CprME, 1prME, 4CprME, and 4prME polypeptides were purified by affinity chromatography and confirmed by western blot using mouse anti-HA tag antibody for DENV-1 constructs (Fig. 2a, b) and antistrap tag II antibody for DENV-4 constructs, which showed bands of size $55 \mathrm{kDa}$ at elution fractions (Fr), respectively. To determine whether the purified 1CprME, 1 prME, 4CprME, and 4prME polypeptides contained E proteins, western blotting was performed using serotype-specific monoclonal anti-envelope antibodies, an anti-E DENV-1 E29 clone for DENV-1 constructs, and an anti-E DENV-4 E42 clone for DENV4 constructs. All of the constructs' bands were confirmed to be approximately $55 \mathrm{kDa}$ (Fig. 2e, f). These results demonstrate that the E proteins were present in the purified $1 \mathrm{CprME}$, $1 \mathrm{prME}$, 4CprME, and 4prME polypeptides. Anti-E-DENV-1 E29 clone, Anti-E-DENV-2 3H5-1 clone, Anti-E-DENV-3 E1 clone, and Anti-EDENV-4 E42 clone antibodies were used to investigate the cross-reactivity of all purified proteins. Specific bands for 1CprME (Fig. 3a), 1prME (Fig. 3b), 4CprME (Fig. 3c), and 4prME (Fig. 3d) could not be detected using the specific serotype antibodies. These results indicate that there is no cross-reactivity between specific serotype antibodies and all of the constructs.

\section{Morphology of 1CprME, 1prME, 4CprME and 4prME polypeptides}

IEM was used to confirm the morphology of the polypeptides 1CprME, 1prME, 4CprME, and 4prME. Spherical structures with sizes ranging from 30 to $55 \mathrm{~nm}$ were observed (Fig. 4a-d), supported by data from dynamic light scattering (Fig. 4e-h). The IEM observation revealed that the particles were lipid bilayer-structured spherical, with some immunogold bound to their surface. The presence of anti-dengue E protein in gold nanoparticles bound to the surface of spherical structures indicates that the particles contain dengue E protein on the surface of the VLPs. According to these results, the $1 \mathrm{CprME}, 1 \mathrm{prME}$, 4CprME, and 4prME polypeptides expressed in silkworms are capable of generating VLPs of Dengue-1 and -4 (DENV-LPs/1CprME, DENV-LPs/1prME, DENV-LPs/4CprME, and DENV-LPs/4prME). 
To confirm the expression of EDIII on the surface of DENV-LPS, a heparin-binding assay was performed. The binding assay of the purified DENV-LPs/1CprME, /1 prME, /4CprME, and /4prME was performed using heparin-immobilized microtiter plates. In ELISA, the absorbance increased proportionally to the presence of $E$ (Fig. 5a). These results indicate that the EDIII domain is present on the surface of the DENV-LPs of 1 CprME, 1 prME, 4 CprME, and 4prME.

\section{Isothermal Titration Calorimetry assay for heparin-binding to DENV-LPs}

Binding activities of DENV-LPs/1CprME, /1 prME, /4CprME, and /4prME toward heparin were investigated by ITC (Fig. $5 \mathrm{~b}-\mathrm{e}$ ). Heparin binds to DENV-LPs with $K_{\mathrm{D}}$ values of $21-51 \mathrm{mM}$ and $\Delta G$ values from - 5.5 to $6.2 \mathrm{kcal} \mathrm{mol}^{-1}$ (Table 2). $K_{\mathrm{D}}$ values, $29.5 \mathrm{mM}$ of DENV-LPs/1CPrME or $21.1 \mathrm{mM}$ of /4CprME were 1.7-fold lower compared to $51.0 \mathrm{mM}$ of DENV-LPs/1prME or $36.2 \mathrm{mM}$ of /4prME, suggesting CprMEs are higher affinity to heparin than prMEs which are the similar results of ELISA (Fig. $5 \mathrm{a}$ ). $\triangle G$ value of DENVLPs/1CprME or /4CprME was lower than that of DENV-LPs/1PrME or /4prME, indicating that the heparin binding to the EDIII on CprMEs are more spontaneous than to prMEs.

Table 2 The binding affinity of DENV-LPs towards heparin.

\section{Human DENV-infected sera interaction with DENV-LPs}

Purified DENV-LPs/1CprME, /1prME, /4CprME, and /4prME were characterized for their antigenicity toward the patient sera by direct ELISA. As shown in ELISA analysis, DENV-LPs/1CprME, /1prME, /4CprME, and /4prME showed reactivity to patient sera compared to PBS and the rabbit anti-DENV E polyclonal antibody as a positive control (Fig. 6a). DENV-LPs/1CprME, /1prME, /4CprME, and /4prME to patient sera showed significantly high responses compared to anti-E antibody. The Welch t-test showed a significant difference $(p<0.001)$ between DENV-LPs-patient sera reactivity to DENV-LPs-positive control or to PBS.

\section{DENV-LPs/1CprME, /1prME, /4CprME and /4prME elicited virus-specific IgG}

$\mathrm{BALB} / \mathrm{c}$ mice were immunized three times at three-week intervals with $50 \mathrm{mg}$ of DENV-LPs/1CprME, /1prME, /4CprME, and /4prME with an alhydrogel adjuvant injected intraperitoneally. ELISA was used to measure serum titers in mice two weeks after their last immunization. DENV-LPs/1CprME, /1 prME, /4CprME, and /4prME induced antibody production. The anti-1CprME Ab, anti-1prME Ab, anti-4CprME Ab, and anti-4prME Ab were tested for specific binding using their antigens. The anti-1CprME and anti4CprME antibodies had high affinities for their respective DENV-LPs (Fig. 6b). Anti-1 prME Ab and anti4prME Ab, on the other hand, recognized DENV-LPs/1prME and DENV-LPs/4prME, respectively. Adjuvants increase immune responses to all antibodies, as shown in this study. Therefore, DENV-LPs/CprME are more effective at eliciting particular antibodies than DENV-LPs/prME.

\section{Discussion}




\begin{tabular}{|c|c|c|c|c|c|c|c|c|}
\hline Protein & $\begin{array}{l}K_{\mathrm{D}} \\
(\mathrm{M})\end{array}$ & $\begin{array}{l}K_{\mathrm{a}} \\
\left(\mathrm{M}^{-}\right. \\
\left.{ }^{1}\right)\end{array}$ & $\mathbf{N}$ & $\begin{array}{l}\Delta G \\
(\mathrm{kcal} \\
\left.\mathrm{mol}^{-1}\right)\end{array}$ & Ligand & Host & Method & Ref. \\
\hline $\begin{array}{l}\text { DENV- } \\
\text { LP/1CprME }\end{array}$ & $\begin{array}{l}29.5 \\
' 10^{-6}\end{array}$ & $\begin{array}{l}3.38 \\
' 10^{4}\end{array}$ & 3.86 & -5.96 & Heparin & $\begin{array}{l}B . \\
\text { mori }\end{array}$ & ITC & $\begin{array}{l}\text { This } \\
\text { study }\end{array}$ \\
\hline $\begin{array}{l}\text { DENV- } \\
\text { LP/1prME }\end{array}$ & $\begin{array}{l}51.0 \\
' 10^{-6}\end{array}$ & $\begin{array}{l}1.93 \\
' 10^{4}\end{array}$ & 3.32 & -5.55 & Heparin & $\begin{array}{l}B . \\
\text { mori }\end{array}$ & ITC & $\begin{array}{l}\text { This } \\
\text { study }\end{array}$ \\
\hline $\begin{array}{l}\text { DENV- } \\
\text { LP/4CprME }\end{array}$ & $\begin{array}{l}21.1 \\
' 10^{-6}\end{array}$ & $\begin{array}{l}4.75 \\
' 10^{4}\end{array}$ & 5.43 & -6.24 & Heparin & $\begin{array}{l}B . \\
\text { mori }\end{array}$ & ITC & $\begin{array}{l}\text { This } \\
\text { study }\end{array}$ \\
\hline $\begin{array}{l}\text { DENV- } \\
\text { LP/4prME }\end{array}$ & $\begin{array}{l}36.2 \\
10^{-6}\end{array}$ & $\begin{array}{l}2.76 \\
' 10^{4}\end{array}$ & 5.00 & -5.85 & Heparin & $\begin{array}{l}\text { B. } \\
\text { mori }\end{array}$ & ITC & $\begin{array}{l}\text { This } \\
\text { study }\end{array}$ \\
\hline $\begin{array}{l}\text { DENV-2 E } \\
\text { protein }\end{array}$ & $\begin{array}{l}5.0 \\
' 10^{-9}\end{array}$ & - & - & - & $\begin{array}{l}\text { O-sulfated } \\
\text { heparin }\end{array}$ & $\begin{array}{l}E . \\
\text { coli }\end{array}$ & SPR & $\begin{array}{l}\text { Marks } \\
\text { et al. } \\
2001\end{array}$ \\
\hline $\begin{array}{l}\text { DENV-2 E } \\
\text { protein }\end{array}$ & $\begin{array}{l}5.0 \\
' 10^{-9}\end{array}$ & - & - & - & $\begin{array}{l}\mathrm{N} \text { - and } \mathrm{O}- \\
\text { sulfated heparin }\end{array}$ & $\begin{array}{l}E . \\
\text { coli }\end{array}$ & SPR & $\begin{array}{l}\text { Marks } \\
\text { et al. } \\
2001\end{array}$ \\
\hline $\begin{array}{l}\text { DENV-2 E } \\
\text { protein }\end{array}$ & $\begin{array}{l}15.0 \\
' 10^{-9}\end{array}$ & - & - & - & Heparin & $\begin{array}{l}\text { cos- } \\
7\end{array}$ & ITC & $\begin{array}{l}\text { Chen et } \\
\text { al. } \\
1997\end{array}$ \\
\hline ZIKV-E & $\begin{array}{l}433.0 \\
' 10^{-9}\end{array}$ & - & - & - & Heparin & $\begin{array}{l}\text { E. } \\
\text { coli }\end{array}$ & SPR & $\begin{array}{l}\text { Kim et } \\
\text { al. } \\
2017\end{array}$ \\
\hline
\end{tabular}

Previously, DENV-LP/2 was expressed in silkworm larval hemolymph, and DENV-LP/3 was expressed in silkworm larval fat bodies by removing capsid-anchor in the capsid region (Utomo et al. 2019; Utomo et al. 2020). However, the expressed 1 CprME, 1prME, 4CprME, and 4prME polypeptides were detected in hemolymph by adding anchor $\mathrm{c}$ to the capsid region.

The interaction between heparin and DENV-LPs has been analyzed using multiple assays, including ELISA with immobilized heparin and ITC. Heparin binds to DENV-LPs with $K_{\mathrm{D}}$ values of $21-51 \mathrm{mM}$ and $\Delta G$ values from - 5.5 to $-6.2 \mathrm{kcal} \mathrm{mol}^{-1}$ using the ITC system. According to other references, Marks et al. (2001) used $\mathrm{O}$-sulfated heparin or $\mathrm{N}$ - and $\mathrm{O}$-sulfated heparin to bind to the DENV-2 envelope protein expressed in $E$. coli and analyzed using SPR, yielding a $K_{\mathrm{D}}$ of $5 \mathrm{nM}$. Chen et al. (1997) used heparin to analyze the binding to the DENV-2 envelope protein expressed on COS-7 mammalian cells. They determined the $K_{\mathrm{D}}$ to be $15 \mathrm{nM}$ using ITC. Kim et al. (2017) used heparin to analyze the binding of the ZIKV envelope protein expressed in $E$. coli and determined the $K_{\mathrm{D}}$ to be $433 \mathrm{nM}$ using SPR (Table 2). In comparison to a protein subunit, VLPs are a complex molecule composed of several protein subunits. It is known that the affinity of the ligand-protein is based on the surface's interaction, leading to the 
conjugation within the pocket of the protein. Hence, according to the structure of the VLP, it is considered relatively high molar mass of macromolecules which affect the equilibrium and kinetics of its protein function. Consequently, the low effective molar concentration of a VLP results to low surface available for binding and result to overall affinity of a VLP binding being underestimated. Regarding antiviral activity, sulfated heparin has better binding ability than heparin. Therefore, sulfated heparin is used to inhibit viral infection of cells. However, unmodified heparin in the cell membrane is known to bind and interact with EDIII, the putative receptor-binding domain in the flavivirus E protein crystal structure (Frei et al. 2018; Han et al. 2018; Yang et al. 2016; Zautner et al. 2006). EDIII also contains epitopes that block viral adsorption and are targeted by many antibodies, including serotype-specific neutralizing monoclonal antibodies. The conformational flexibility of heparin might permit this molecule to more easily adopt a productive conformation for interaction with the envelope protein. Although it has only a moderate binding affinity, the envelope of DENV-LP is still recognized by heparin on the surface of the cell (Hyatt et al. 2020; Marks et al. 2001). While mammalian cells secrete proteins with correct conformations and full biological activity, insect cells offer advantages comparable to those of mammalian cells when compared to $E$. coli or yeast expression systems. The ability to introduce foreign DNA into these cells facilitates a better understanding of the transcriptional, translational, and posttranslational machinery in mammalian cells (Gray 2001; Ikonomou et al. 2003).

The antigens of $1 \mathrm{CprME}, 1 \mathrm{prME}, 4 \mathrm{CprME}$, and $4 \mathrm{prME}$ also showed reactivity to patient sera high affinity in the direct ELISA. Mixed sera of dengue patients can react to many types of nonspecific DENV epitopes. The strongly correlated reactivities of patient sera with DENV-LPs indicated that the same epitope(s) were displayed on these DENV-LPs. However, there will be a marked difference in the level of antibody reactivity. In other words, the epitope(s) displayed on the DENV-LP surface is comparable with those of the native dengue virus (Danko et al. 2018; Wang et al. 2003).

DENV-LPs/1CprME, /1prME, /4CprME, and / 4prME could generate lgG antibody levels since many VLPs include structural or molecular characteristics that give certain auto-immunostimulatory qualities. These features enable VLPs to induce immunological responses without the use of adjuvants; nevertheless, adjuvants may enhance vaccination immunogenicity and encourage the activation of a specific type of immune response when combined with VLP vaccines (Cimica and Galarza 2017; Donaldson et al. 2018; Müller et al. 2020). Our ITC data indicate that DENV-LP/1CPrME and DENV-LPS/4CPrME have a lower $K_{D}$ and $\Delta G$ than DENV-LP/1prME and DENV-LPs/4prME. This demonstrates that the CPrME constructs have a higher affinity and more spontaneous binding then the prME constructs. Those reactions can be harnessed to perform work inside the body. The IgG elicitation in mice confirmed DENV-LP/CPrMEs elicit a stronger immune response than DENV-LPs/prMEs, indicates CprME can easily bind to heparin-like receptor on the surface of the cells compare to prME. When mice were immunized with flavivirus VLPs, CPrME VLPs exhibited superior antigenicity to prME VLPs. Due to the superiority of the CprME VLP, a capsid should be included in the vaccine to improve immunity. This repetitive protein structure can boost innate immunity and prompt B cells to directly generate neutralizing antibodies (Garg et al. 2019; Nooraei et al. 2021). Each DENV serotype carries the conserved antibody epitope incorporated in the $\mathrm{N}$ - and C- 
terminal regions of the $\mathrm{C}$ protein and is efficiently recognized by dengue patients exposed to primary and secondary infections from other serotypes. The C-protein central region has an epitope of the peptide, primarily targeted by serotype-specific antibodies (Alves et al. 2016; Nadugala et al. 2017; Rana et al. 2018).

\section{Abbreviations}
Ab: Antibody
C: Capsid protein

DENV: Dengue virus

DENV-LP: Dengue virus-like particle

$K_{\mathrm{a}}:$ Association constant

$K_{\mathrm{D}}:$ Dissociation constant

DLS: Dynamic light scattering

E: Envelope protein

ELISA: Enzyme-linked immunosorbent assay

EDIII: Envelope protein domain III

D G: Gibbs free energy

HRP: Horseradish peroxidase

IEM: Immunoelectron microscopy

ITC: Isothermal Titration Calorimetry

M: Membrane protein

PBS: Phosphate-buffered saline

PBST: Phosphate-buffered saline containing $0.1 \%$ Tween 20

PCR: Polymerase chain reaction

prM: Premembrane protein

TBS: Tris-buffered saline 
TBST: Tris-buffered saline containing $0.1 \%$ Triton X-100

TEM: Transmission electron microscopy

TMB: 3.3',5.5'-tetramethylbenzidine

VLP: viral-like particle

WHO: World health organization

\section{Declarations}

\section{Ethical approval and consent to participate}

Dengue patient sera were obtained from the Centre of Pharmaceutical and Medical Technology, National Research and Innovation Agency, Jakarta, Indonesia. Serum collection protocols were reviewed and approved by the Health Research Ethics Committee-University of Indonesia and Cipto Mangunkusumo Hospital (HREC-FMUI/CMH) (approval no. KET-1358/UN2.F1/ETIK/PPM.00.02/2020). Animal experimental protocols were reviewed and approved by the Research Ethical Committee of the Faculty of Medicine, Universitas Indonesia (No. KET-721/UN2.F1/ETIK/PPM.00.02/2021). All applicable international, national, and/or institutional guidelines for the care and use of animals were followed.

\section{Consent for publication}

Not applicable.

\section{Availability of data and material}

All the data and materials have been provided in the main manuscript.

\section{Competing interests}

The authors declare that they have no competing interests.

\section{Funding information}

This work has been funded by the Japan Society for the Promotion of Science (JSPS) KAKENHI Grant-inAid for Scientific Research (A) (Grant No. 20H00411) and partly (16H02544) and partly by the Heiwa Nakajima Foundation's Asian region priority academic research grant.

\section{Authors' contribution}

DISU was the main researcher for this study and was involved with the experimental design and operation. SP participated in animal experiments and provided resources, respectively. EYP provided 
ideas, funded the research, revised the manuscript, and supervised this study. All authors read and approved the manuscript.

\section{Acknowledgments}

We would like to thank Dr. Etik Mardliati, Mr. Julham Effendi of Center of Pharmaceutical and Medical Technology, National Research and Innovation Agency (BRIN), Indonesia for the animal experiments.

\section{Author's information}

${ }^{1}$ Laboratory of Biotechnology, Department of Bioscience, Graduate School of Science and Technology, Shizuoka University, 836 Ohya, Suruga-ku, Shizuoka 422-8529, Japan. ${ }^{2}$ Center of Pharmaceutical and Medical Technology, Agency for the Assessment and Application of Technology, Jl. Kawasan Puspiptek, Gedung I LAPTIAB, Kota Tangerang Selatan, Banten 15314, Indonesia. ${ }^{3}$ Laboratory of Biotechnology, Research Institute of Green Science and Technology, Shizuoka University, 836 Ohya, Suruga-ku, Shizuoka 422-8529, Japan

\section{References}

Alves R, Pereira LR, Fabris DLN, Salvador FS, Santos RA, Zanotto PMA, Romano CM, Amorim JH, Ferreira LCS (2016) Production of a recombinant dengue virus 2 NS5 protein and potential use as a vaccine antigen. Clin. Vaccine Immunol. 23(6):460-469 doi:10.1128/CVI.00081-16

Bhatt P, Sabeena SP, Varma M, Arunkumar G (2021) Current understanding of the pathogenesis of dengue virus infection. Curr. Microbiol. 78(1):17-32 doi:10.1007/s00284-020-02284-w

Boonyakida J, Xu J, Satoh J, Nakanishi T, Mekata T, Kato T, Park EY (2021) Identification of antigenic domains and peptides from VP15 of white spot syndrome virus and their antiviral effects in Marsupenaeus japonicus. Sci. Rep. 11(1):12766 doi:10.1038/s41598-021-92002-8

Cimica V, Galarza JM (2017) Adjuvant formulations for virus-like particle (VLP) based vaccines. Clin Immunol. 183:99-108 doi:https://doi.org/10.1016/j.clim.2017.08.004

Danko JR, Kochel T, Teneza-Mora N, Luke TC, Raviprakash K, Sun P, Simmons M, Moon JE, De La Barrera R, Martinez LJ, Thomas SJ, Kenney RT, Smith L, Porter KR (2018) Safety and immunogenicity of a tetravalent dengue DNA vaccine administered with a cationic lipid-based adjuvant in a phase 1 clinical trial. Am. J. Trop. Med. Hyg. 98(3):849-856 doi:10.4269/ajtmh.17-0416

Donaldson B, Lateef Z, Walker GF, Young SL, Ward VK (2018) Virus-like particle vaccines: immunology and formulation for clinical translation. Expert Rev. Vaccines 17(9):833-849

doi:10.1080/14760584.2018.1516552 
Duff MR, Jr., Grubbs J, Howell EE (2011) Isothermal titration calorimetry for measuring macromoleculeligand affinity. J Vis Exp. (55):2796 doi:10.3791/2796

Frei JC, Wirchnianski AS, Govero J, Vergnolle O, Dowd KA, Pierson TC, Kielian M, Girvin ME, Diamond MS, Lai JR (2018) Engineered dengue virus domain III proteins elicit cross-neutralizing antibody responses in mice. J Virol. 92(18) :e01023-18 doi:10.1128/JVI.01023-18

Fujita R, Hino M, Ebihara T, Nagasato T, Masuda A, Lee JM, Fujii T, Mon H, Kakino K, Nagai R, Tanaka M, Tonooka Y, Moriyama T, Kusakabe T (2020) Efficient production of recombinant SARS-CoV-2 spike protein using the baculovirus-silkworm system. Biochem. Biophys. Res. Commun. 529(2):257-262 doi:https://doi.org/10.1016/j.bbrc.2020.06.020

Garg H, Mehmetoglu-Gurbuz T, Ruddy GM, Joshi A (2019) Capsid containing virus like particle vaccine against zika virus made from a stable cell line. Vaccine 37(48):7123-7131

doi:10.1016/j.vaccine.2019.09.093

Gray D (2001) Overview of protein expression by mammalian cells. Current protocols in protein science Chapter 5(1):Unit5.9-Unit5.9 doi:10.1002/0471140864.ps0509s10

Han S-C, Huy N-X, Kim M-Y (2018) Enhanced expression of dengue virus EDIII-based tetravalent antigen protein using transgenic rice callus. Plant Biotechnol. Rep. 12(3):207-215 doi:10.1007/s11816-018-04876

Hyatt JG, Prévost S, Devos JM, Mycroft-West CJ, Skidmore MA, Winter A (2020) Molecular changes in dengue envelope protein domain III upon interaction with glycosaminoglycans. Pathogens 9(11):935 doi: $10.3390 /$ pathogens 9110935

Ikegaya M, Miyazaki T, Park EY (2021) Biochemical characterization of Bombyx mori a-Nacetylgalactosaminidase belonging to the glycoside hydrolase family 31. Insect Mol. Biol. 30(4): 367378 doi:https://doi.org/10.1111/imb.12701

Ikonomou L, Schneider YJ, Agathos SN (2003) Insect cell culture for industrial production of recombinant proteins. Appl. Microbiol. Biotechnol. 62(1):1-20 doi:10.1007/s00253-003-1223-9

Kato T, Kajikawa M, Maenaka K, Park EY (2010) Silkworm expression system as a platform technology in life science. Appl Microbiol Biotechnol. 85(3):459-70 doi:10.1007/s00253-009-2267-2

Krol E, Brzuska G, Szewczyk B (2019) Production and biomedical application of flavivirus-like particles. Trends Biotechnol. 37(11):1202-1216 doi:10.1016/j.tibtech.2019.03.013

Maesaki R, Satoh R, Taoka M, Kanaba T, Asano T, Fujita C, Fujiwara T, Ito Y, Isobe T, Hakoshima T, Maenaka K, Mishima M (2014) Efficient and cost effective production of active-form human PKB using silkworm larvae. Sci. Rep. 4(1):6016 doi:10.1038/srep06016 
Marks RM, Lu H, Sundaresan R, Toida T, Suzuki A, Imanari T, Hernáiz MJ, Linhardt RJ (2001) Probing the interaction of dengue virus envelope protein with heparin: assessment of glycosaminoglycan-derived inhibitors. J. Med. Chem. 44(13):2178-2187 doi:10.1021/jm000412i

Müller H, Fehling SK, Dorna J, Urbanowicz RA, Oestereich L, Krebs Y, Kolesnikova L, Schauflinger M, Krähling V, Magassouba NF, Fichet-Calvet E, Ball JK, Kaufmann A, Bauer S, Becker S, von Messling V, Strecker T (2020) Adjuvant formulated virus-like particles expressing native-like forms of the lassa virus envelope surface glycoprotein are immunogenic and induce antibodies with broadly neutralizing activity. npj Vaccines 5(1):71 doi:10.1038/s41541-020-00219-x

Nadugala MN, Jeewandara C, Malavige GN, Premaratne PH, Goonasekara CL (2017) Natural antibody responses to the capsid protein in sera of dengue infected patients from Sri Lanka. PLoS One 12(6):e0178009 doi:10.1371/journal.pone.0178009

Nishiura H, Halstead SB (2007) Natural history of dengue virus (DENV) -1 and DENV -4 infections: reanalysis of classic studies. J. Infect. Dis. 195(7):1007-1013 doi:10.1086/511825

Noad R, Roy P (2003) Virus-like particles as immunogens. Trends Microbiol. 11(9):438-444 doi:10.1016/S0966-842x(03)00208-7

Nooraei S, Bahrulolum H, Hoseini ZS, Katalani C, Hajizade A, Easton AJ, Ahmadian G (2021) Virus-like particles: preparation, immunogenicity and their roles as nanovaccines and drug nanocarriers. J. Nanobiotechnology 19(1):59 doi:10.1186/s12951-021-00806-7

Rana J, Slon Campos JL, Leccese G, Francolini M, Bestagno M, Poggianella M, Burrone OR (2018) Role of capsid anchor in the morphogenesis of zika virus. J. Virol. 92(22) e01174-18 doi:10.1128/JVI.01174-18

Redoni M, Yacoub S, Rivino L, Giacobbe DR, Luzzati R, Di Bella S (2020) Dengue: status of current and under-development vaccines. Rev. Med. Virol. 30(4):e2101 doi:10.1002/rmv.2101

Roldao A, Mellado MC, Castilho LR, Carrondo MJ, Alves PM (2010) Virus-like particles in vaccine development. Expert Rev. Vaccines 9(10):1149-76 doi:10.1586/erv.10.115

Sang S, Liu-Helmersson J, Quam MBM, Zhou H, Guo X, Wu H, Liu Q (2019) The evolutionary dynamics of DENV 4 genotype I over a 60-year period. PLoS Negl. Trop. Dis. 13(7):e0007592 doi:10.1371/journal.pntd.0007592

Suhaimi H, Hiramatsu R, Xu J, Kato T, Park EY (2019) Secretory Nanoparticles of Neospora caninum profilin-fused with the transmembrane domain of GP64 from silkworm hemolymph. Nanomaterials 9(4):593 doi: 10.3390/nano9040593

Utomo DIS, Hirono I, Kato T, Park EY (2019) Formation of virus-like particles of the dengue virus serotype 2 expressed in silkworm larvae. Mol. Biotechnol. 61(11):852-859 doi:10.1007/s12033-019-00210-5 
Utomo DIS, Pambudi S, Sjatha F, Kato T, Park EY (2020) Production of dengue virus-like particles serotype-3 in silkworm larvae and their ability to elicit a humoral immune response in mice. AMB Express 10(1):147 doi:10.1186/s13568-020-01087-3

Villabona-Arenas CJ, Zanotto PMdA (2013) Worldwide spread of dengue virus type 1. PLoS One 8(5):e62649 doi:10.1371/journal.pone.0062649

Vipin Kumar Deo TK (2012) Functional virus-like particles production using silkworm and their application in life science. J. Biotechnol. Biomaterial. s9(01):7 doi:10.4172/2155-952x.S9-001

Wang X, Wang Z, Christensen ND, Dillner J (2003) Mapping of human serum-reactive epitopes in virus-like particles of human papillomavirus types 16 and 11. Virology 311(1):213-221

doi:https://doi.org/10.1016/S0042-6822(03)00179-X

Yang J, Zou L, Yang Y, Yuan J, Hu Z, Liu H, Peng H, Shang W, Zhang X, Zhu J, Rao X (2016) Superficial vimentin mediates DENV-2 infection of vascular endothelial cells. Sci. Rep. 6:38372

doi:10.1038/srep38372

Yousaf M, Junaid K, Iqbal MS, Aslam I, Ahmad S, Aqeel M, Ashfaq UA, Khaliq S, Ghani MU, Waqar N (2018) Analysis of dengue virus burden and serotypes pattern in Faisalabad, 2016-2017. Future Virol. 13(4):245-251 doi:10.2217/fvl-2017-0155

Zautner AE, Jahn B, Hammerschmidt E, Wutzler P, Schmidtke M (2006) N- and 6-O-sulfated heparan sulfates mediate internalization of coxsackievirus B3 variant PD into CHO-K1 cells. J. Virol. 80(13):66296636 doi:10.1128/JVI.01988-05

\section{Figures}




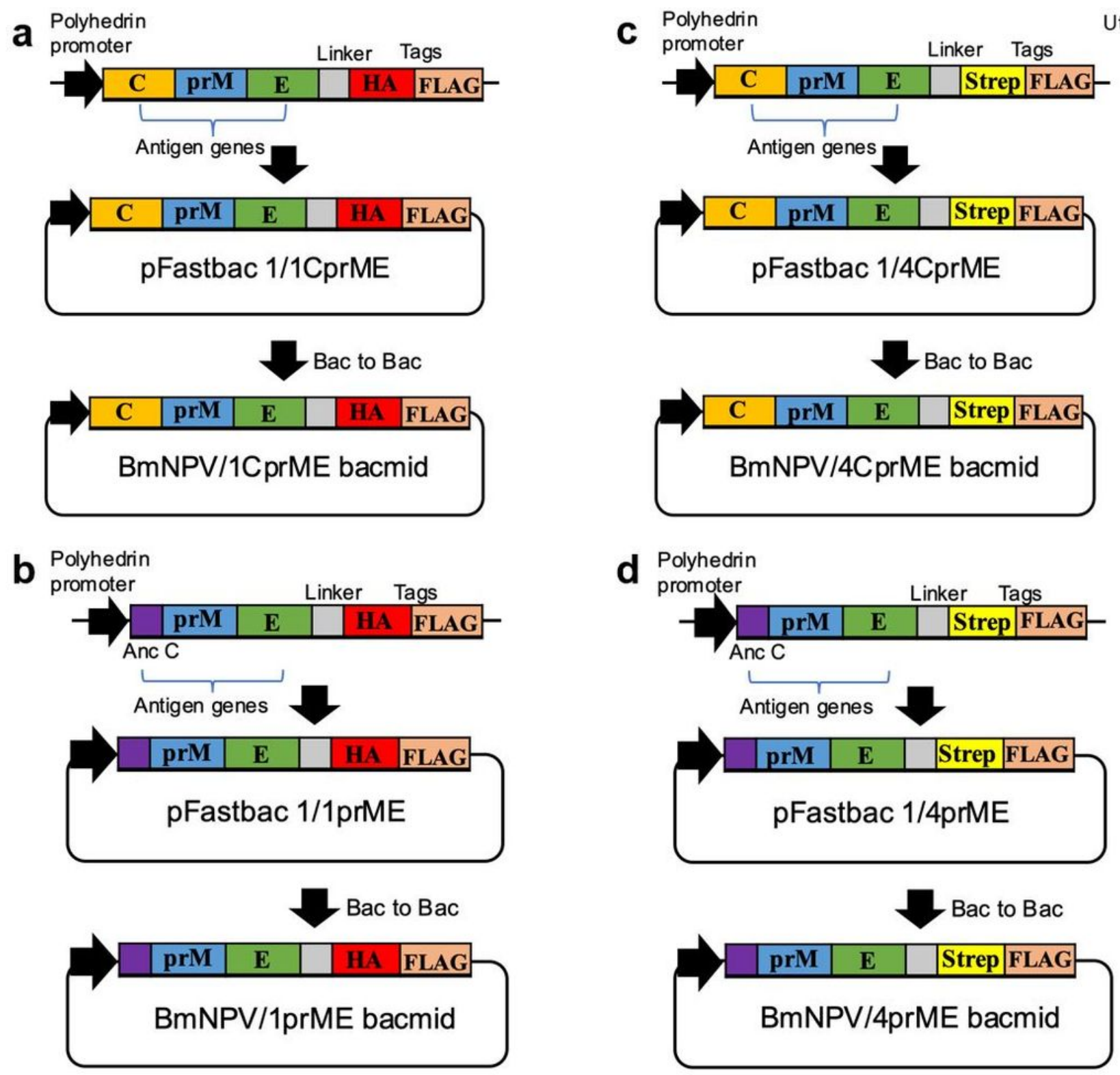

Figure 1

Construction of recombinant dengue virus structural proteins expressed in this study. (a) 1CprME, (b) $1 \mathrm{prME}$, (c) 4CprME, and (d) 4prME polypeptides of DENV-1 and 4 were expressed in silkworms as a fusion protein with HA+FLAG tags for DENV-1 and Strep-tag II+FLAG tags for DENV-4. 


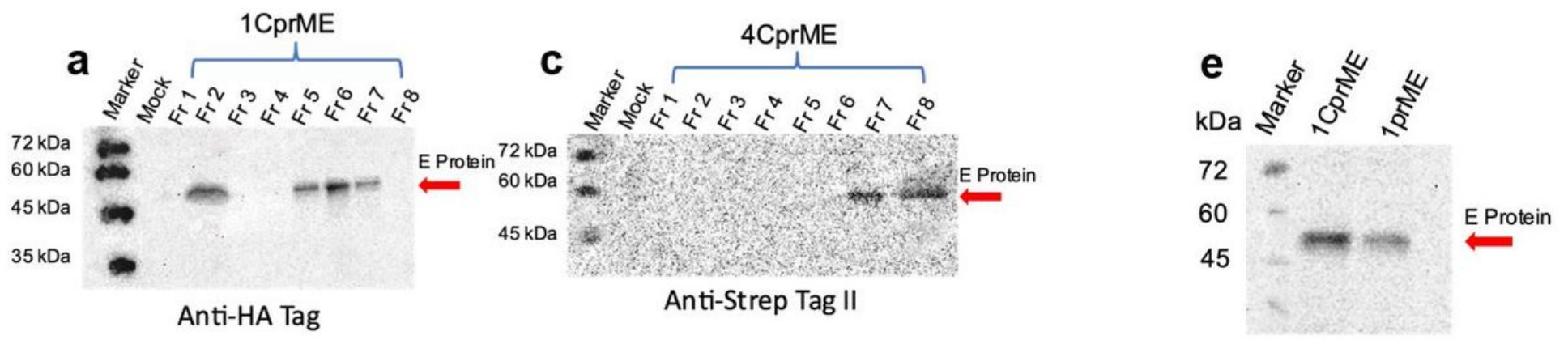

\section{Anti-E DENV-1 E29 clone mAb}

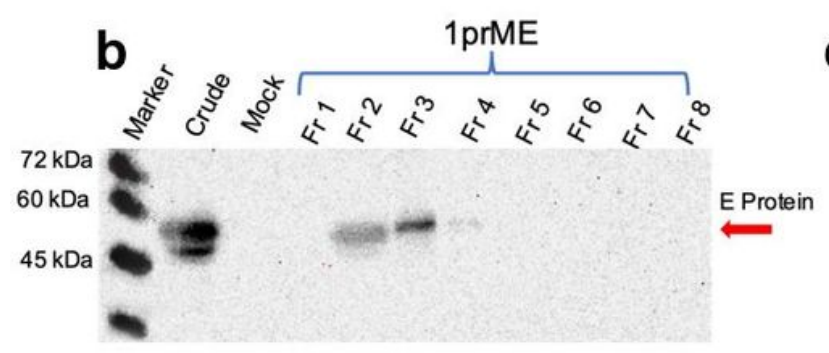

Anti-HA Tag

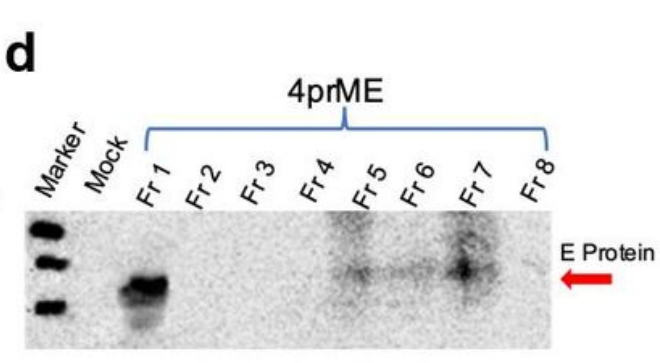

Anti-Strep Tag ॥

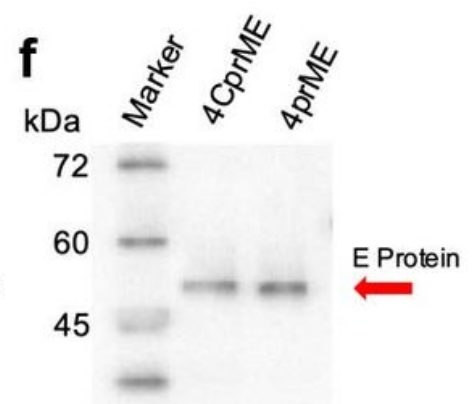

Anti-E DENV-4 E42 clone mAb

Figure 2

Western blot of purified (a) 1CprME, (b) 1prME, (c) 4CprME and (d) 4prME polypeptides. Each protein was purified from silkworm hemolymph using anti-FLAG tag protein purification gel column chromatography. E protein was verified using specific serotype monoclonal antibodies using e an anti-E E29 clone for DENV-1 constructs and $f$ an anti-E E42 clone for DENV-4 antibodies. 


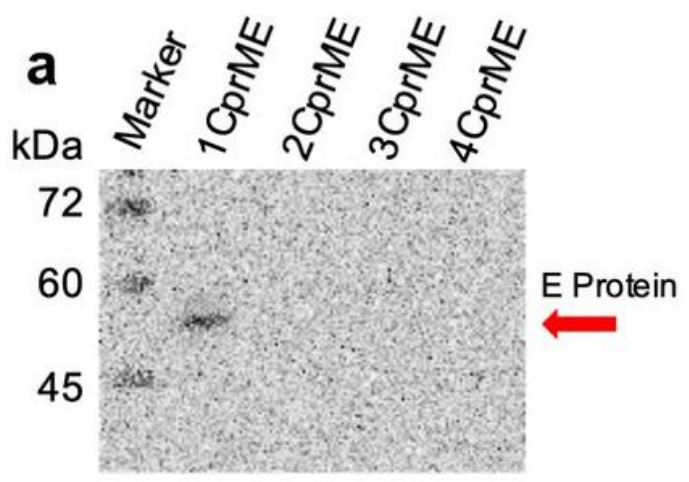

Anti-E DENV-1 E29 clone mAb

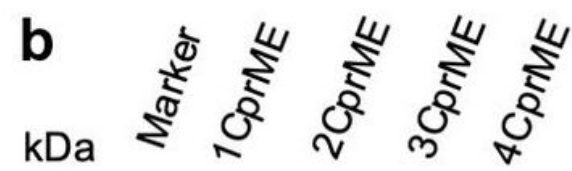

72

60

45

E Protein

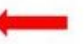

Anti-E DENV-2 3H5-1 clone mAb

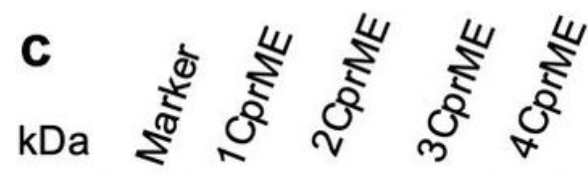

72

60

E Protein

45

Anti-E DENV-3 E1 clone mAb

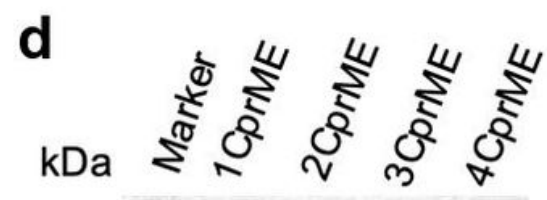

72

60

E Protein

45

Anti-E DENV-4 E42 clone mAb

Figure 3

Western blot of purified (a) 1CprME, (b) 1prME, (c) 4CprME, and (d) 4prME polypeptides for the crossreaction test was performed on the DENV-1 and DENV-4 constructs with specific serotype monoclonal antibodies for each serotype. 

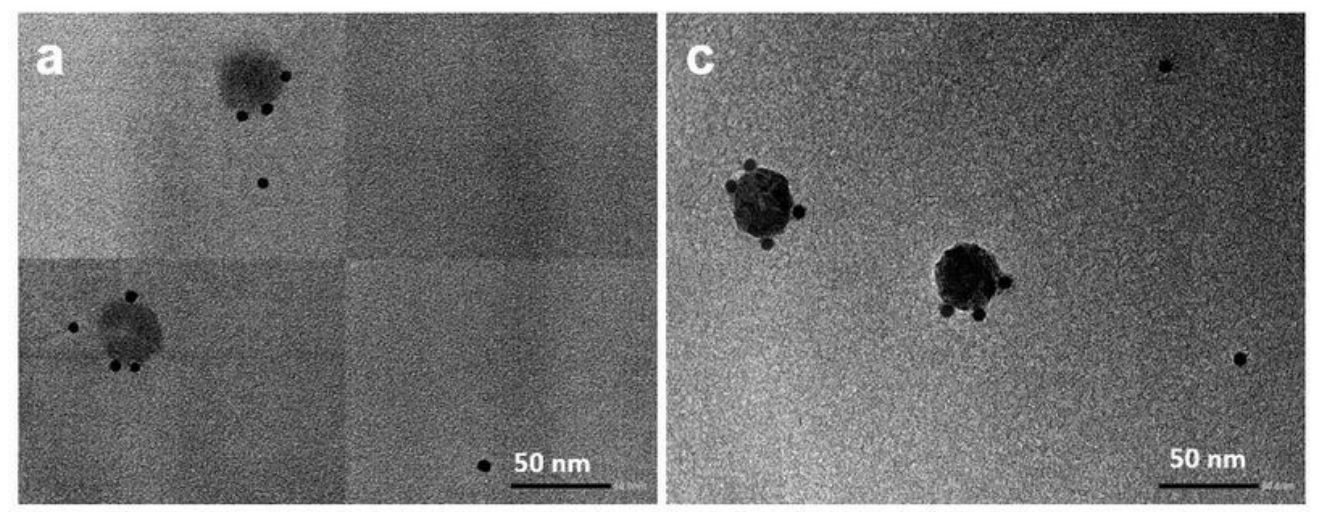

\section{e}
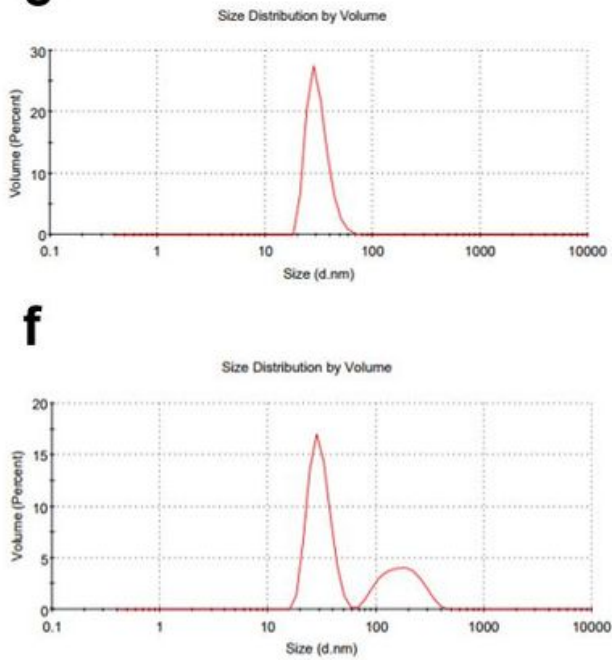

g
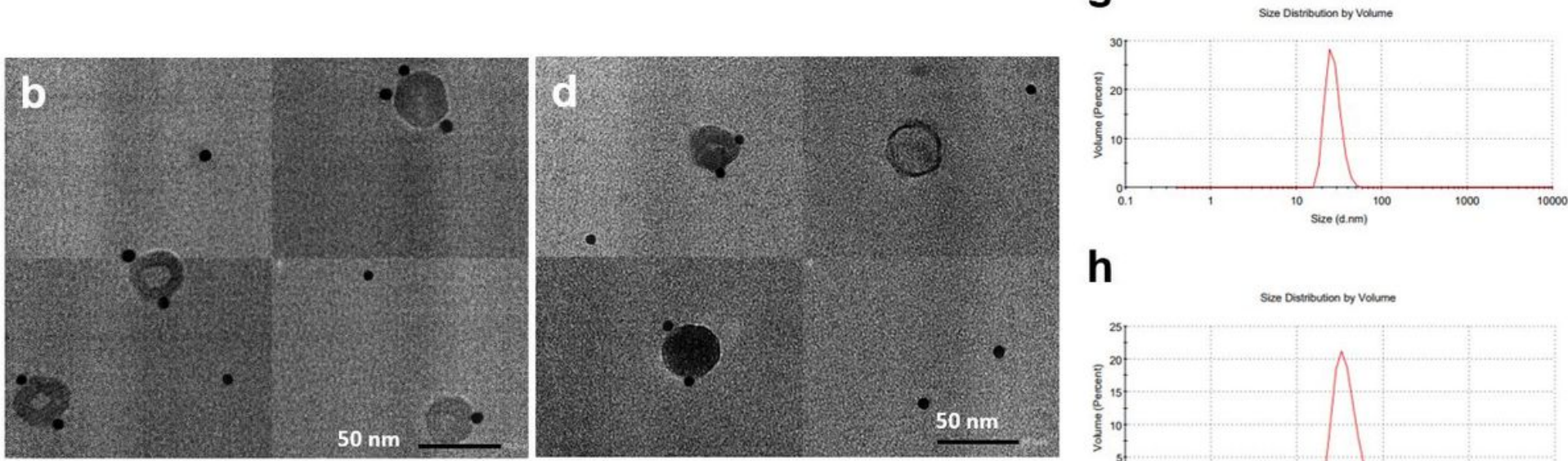

h

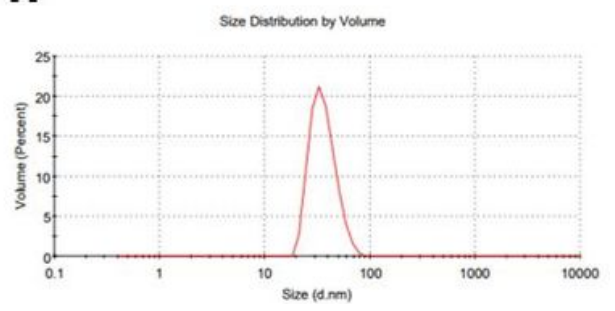

\section{Figure 4}

The purified (a) 1CprME, (b) 1 prME, (c) 4CprME, and (d) 4prME polypeptides were immunogold labeled using an anti-E polyclonal antibody and analyzed by IEM. Black spots in A, B, C, and D indicate the immunogold label. Dynamic light scattering (DLS) was used to analyze the size distributions of (e) 1CprME, (f) 1prME, (g) 4CprME and (h) 4prME polypeptides. 

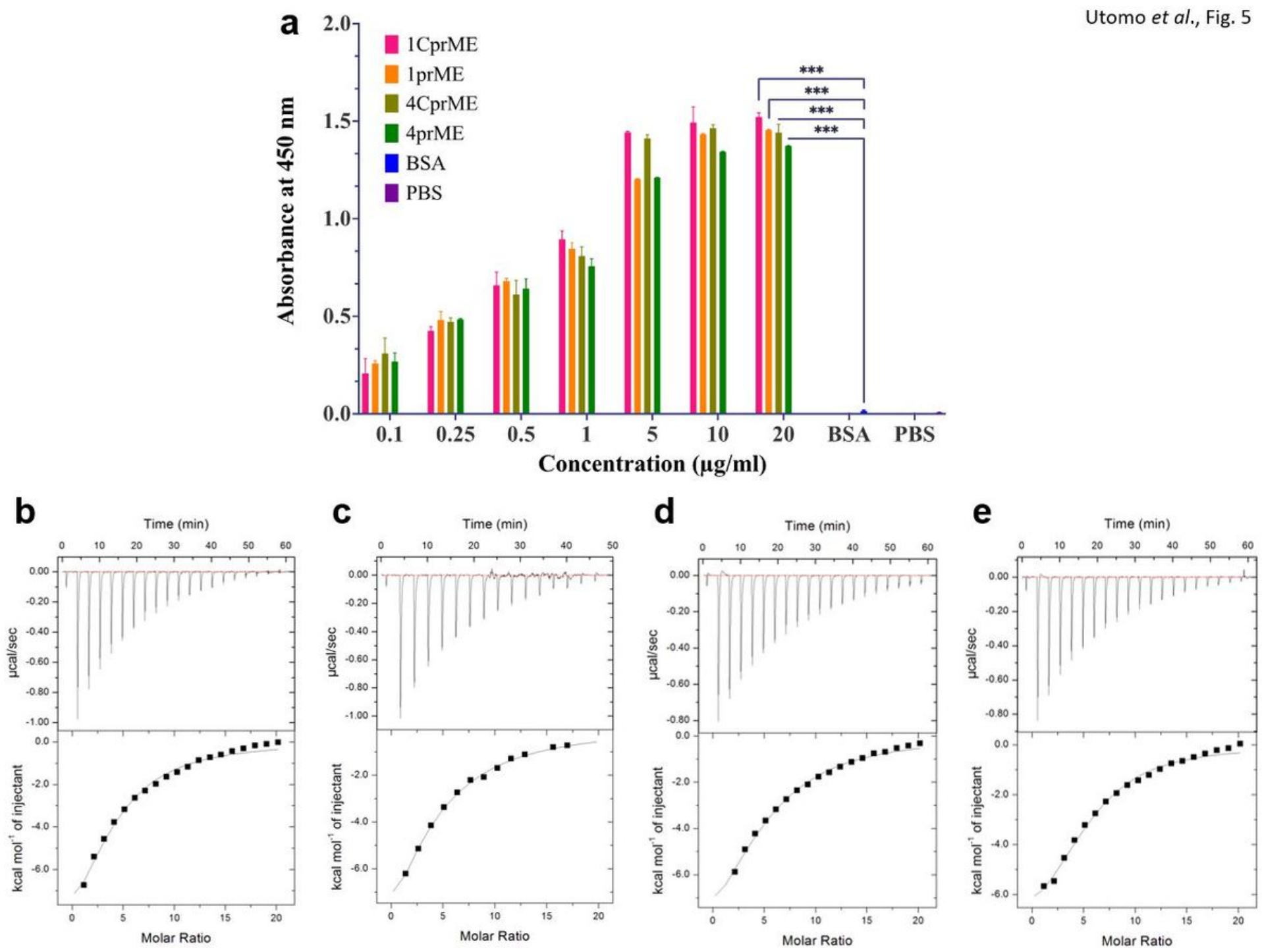

Figure 5

(a) Binding assay of DENV-LPs/1CprME, /1prME, /4CprME, and /4prME to heparin using ELISA. Heparin $(1.8 \mathrm{ng})$ was coated onto each well of an ELISA plate, and each amount of purified protein was used for this ELISA, which was carried out according to the protocol described in the Materials and methods (Welch t-test, $\left.{ }^{*} p<0.05,{ }^{*} p<0.01,{ }^{* \star *} p<0.001\right)$. (b-e) The binding activities between DENV-LPs/1CprME, /1prME, /4CprME, and / 4prME toward heparin were examined by ITC. 


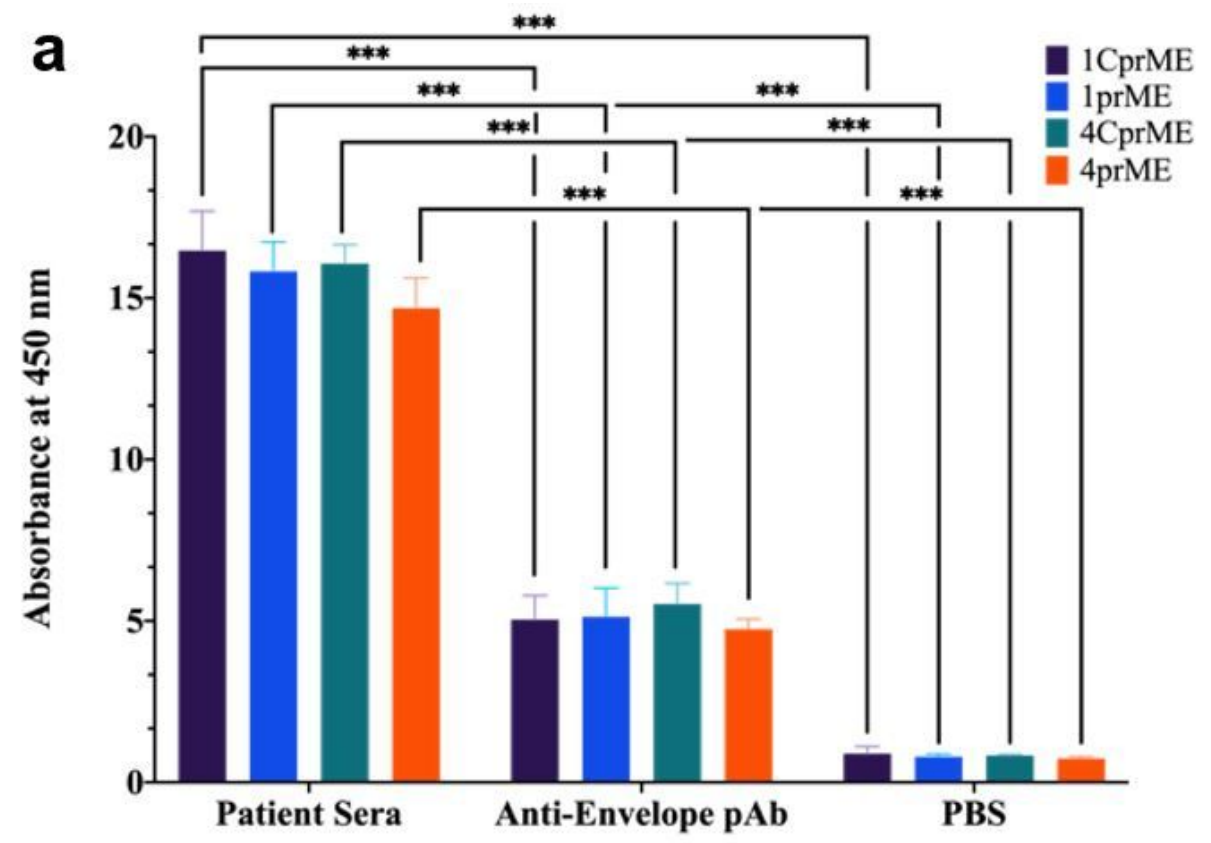

Utomo et al., Fig. 6

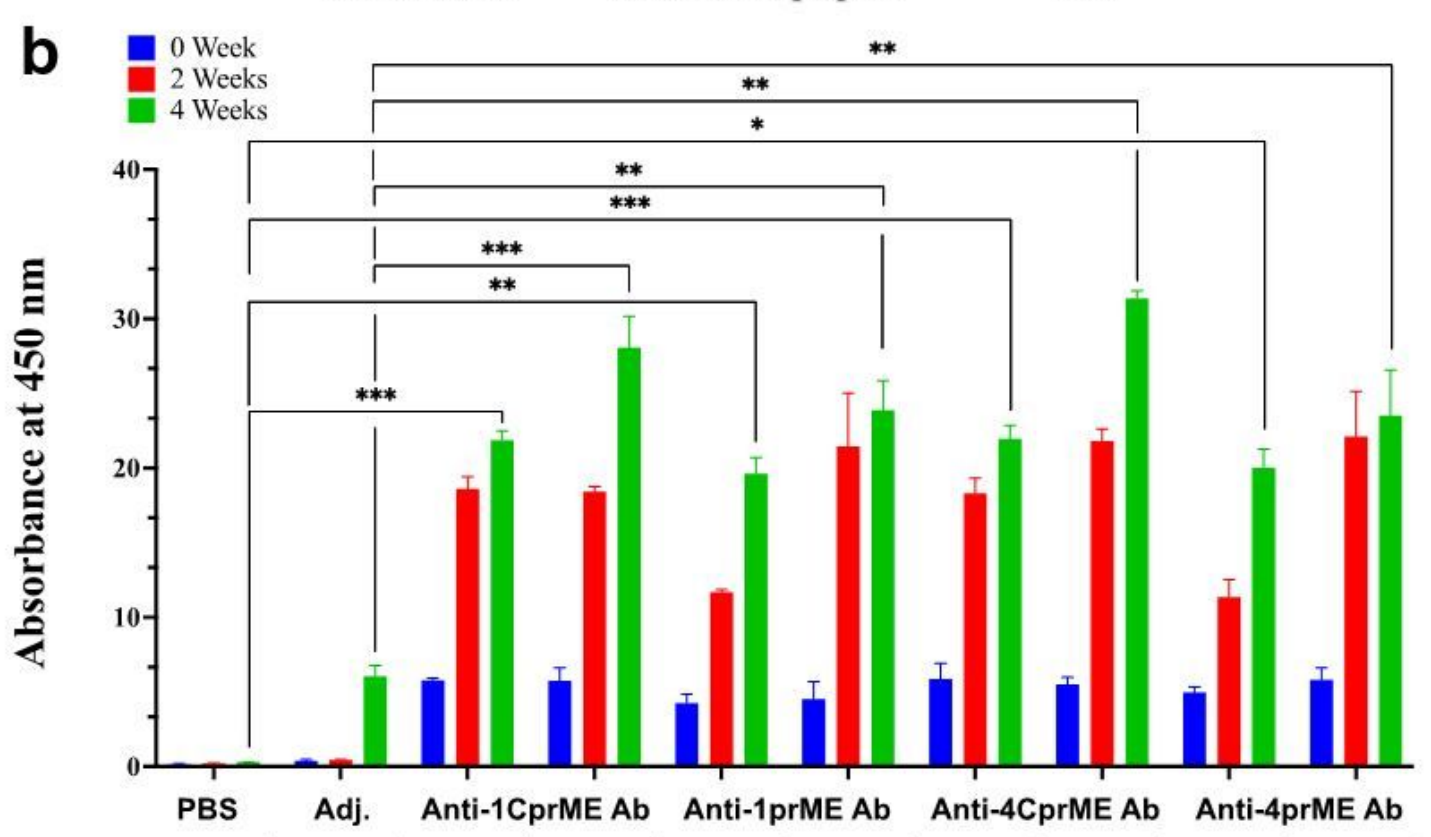

\begin{tabular}{|l|l|l|l|l|l|l|l|l|}
\hline Adj. & - & + & - & + & - & + & - & + \\
\hline
\end{tabular}

Figure 6

(a) The interaction setween DENV-LPs/1CprME, /1prME, /4CprME and /4prME with mixed sera from dengue patients [rapid diagnostic test NS1(+)] were investigated (Welch t-test, ${ }^{*} p<0.05,{ }^{\star \star} p<0.01$, ${ }^{\star * *} \mathrm{p}<0.001$ ). (b) Binding reactions were analyzed using direct ELISA as described. Specific IgG generation by DENV-LPs/1CprME, /1prME, /4CprME and /4prME. BALB/c mice were intraperitoneally immunized with $50 \mu \mathrm{g}$ of monovalent DENV-LPs/1CprME, /1prME, /4CprME and /4prME. At 0, 2 and 4 weeks, sera were collected and used to test for binding of the specific IgG (Welch t-test, ${ }^{*} p<0.05,{ }^{*} \mathrm{p}<0.01$, $\star * \star p<0.001)$.

\section{Supplementary Files}


This is a list of supplementary files associated with this preprint. Click to download.

- SIAMBE.docx 